\title{
AKTIVITAS ANTIOKSIDAN DAN SPF SEDIAAN KRIM TABIR SURYA DARI EKSTRAK ETANOL 70\% KULIT BUAH PISANG AMBON (Musa acuminata Colla)
}

\author{
Herson Cahaya Himawan, ${ }^{1 *}$., Eem Masaenah ${ }^{2}$., Veronika Cahyandari Eko Putri ${ }^{3}$ \\ 1. Program Studi Farmasi Sekolah Tinggi Teknologi Industri dan Farmasi Bogor \\ 2. Program Studi Farmasi Sekolah Tinggi Teknologi Industri dan Farmasi Bogor \\ 3. Mahasiswa Program Studi S1 Farmasi Sekolah Tinggi Teknologi Industri dan Farmasi Bogor \\ *Korespondensi: hersonindonesia2011@gmail.com
}

\begin{abstract}
ABSTRAK
Kulit buah pisang ambon memiliki kandungan antioksidan yang digunakan untuk mencerahkan dan melembabkan kulit. Antioksidan dapat menunda dan mencegah radikal bebas pada kulit. Tujuan penelitian ini untuk membuat sediaan krim tabir surya dari ekstrak etanol 70\% kulit buah pisang ambon dengan mutu fisik yang baik, menentukan aktivitas antioksidan dan nilai Sun Protection Factor (SPF) serta menguji stabilitas sediaan krim tabir surya. Pengujian aktivitas antioksidan menggunakan metode Peredaman Radikal Bebas DPPH, sedangkan penentuan nilai SPF secara in vitro menggunakan spektrofotometer UV-Vis. Hasil penelitian menunjukkan ekstrak etanol $70 \%$ kulit buah pisang ambon dapat dibuat krim yang memiliki mutu fisik baik. Aktivitas antioksidan dari esktrak etanol 70\% kulit pisang ambon dengan nilai inhibisi sebesar 88,12 ppm, sedangkan sediaan krim formula $1(5 \%)$ nilai inhibisi $117 \mathrm{ppm}$, krim formula $2(10 \%)$ nilai inhibisi 107,11 ppm, krim formula $3(15 \%)$ nilai inhibisi $92,04 \mathrm{ppm}$. Nilai SPF pada ekstrak etanol $70 \%$ sebesar 33,30 , pada sediaan krim formula $1(5 \%)$ sebesar 8,61, sediaan krim formula $2(10 \%)$ sebesar 11,65 , sediaan $3(15 \%)$ sebesar 13,72 . Stabilitas sediaan krim stabil pada suhu $25^{\circ} \mathrm{C}$.
\end{abstract}

\section{Kata kunci: Antioksidan, Krim, Kulit Buah Pisang Ambon, SPF}

\begin{abstract}
Ambon banana peel contains antioxidants that are used to brighten and moisturize the skin. Antioxidant can delay and prevent free radicals on the skin. The purpose of this research was to make a sunscreen cream preparation from ethanol $70 \%$ extract of ambon banana peel with good physical quality, activity of antioxidant and Sun Protection Factor (SPF) and the stability of sunscreen cream. The antioxidant activity test used the DPPH method while determining of SPF value in vitro using a UV-Vis Spectrophotometer. The results of this research indicate that extract ethanol $70 \%$ of Ambon banana peel can be made sunscreen cream that has good physical quality. Antioxidant activity ethanol 70\% extract from ambon banana peel with inhibition value of 88,12 ppm, while cream preparation of formula $1(5 \%)$ the inhibition value was $117 \mathrm{ppm}$, formula 2 (10\%) the inhibition value was $107,11 \mathrm{ppm}$, and formula $3(15 \%)$ the inhibition value was 92,04 ppm. The SPF value of ethanol 70\% extract Ambon banana peel was 33,30, in cream preparation formula $1(5 \%)$ was 8,61 , formula $2(10 \%)$ was 11,65 , and formula $3(15 \%)$ was 13,72 . The stability of the cream preparation is stable at $25^{\circ} \mathrm{C}$.
\end{abstract}

Keywords: Ambon banana peel, Antioxidant, Cream, SPF 


\section{PENDAHULUAN}

Sinar matahari sebagai sumber cahaya alami memiliki peranan yang sangat penting bagi keberlangsungan hidup semua mahluk hidup. Selain memberi manfaat, sinar matahari juga dapat memberikan efek yang merugikan untuk kulit terutama jika jumlah paparannya berlebihan. Paparan sinar matahari yang berlebihan akan memberikan efek seperti warna kulit menjadi lebih gelap, eritema, kulit terbakar, pengerutan kulit, penuaan dini, dan kanker kulit. Bahaya dari sinar matahari yaitu radiasi dari sinar ultraviolet (UV) di mana sinar ini berdasarkan panjang gelombang dan efek fisiologik dibedakan menjadi tiga tipe yaitu UV-A (320-360 nm), UV-B (280-320 nm), dan UV-C (100-280 nm). Sinar UV-B lebih merusak kulit karena dapat menyebabkan kulit terbakar dan kanker kulit.

Secara alamiah, manusia memiliki perlindungan terhadap sinar UV dengan cara pengeluaran keringat, penebalan stratum korneum dan pembentukan melanin pada epidermis. Namun paparan sinar UV yang terlalu lama menjadikan sistem alamiah tersebut tidak berfungsi dengan baik sehingga menyebabkan efek merugikan bagi kulit. Oleh karena itu diperlukan senyawa tabir surya untuk melindungi kulit dari radiasi UV secara langsung.

Secara tradisional kulit buah pisang ambon (Musa acuminata Colla) digunakan untuk mencerahkan dan melembabkan kulit wajah. Selama ini kulit buah pisang ambon hanya menjadi sampah organik. Kulit buah pisang ambon (Musa acuminata Colla) memiliki kandungan senyawa aktif yaitu flavonoid, saponin, dan alkaloid serta mengandung karbohidrat, lemak, protein dan kalsium yang dapat mempertahankan minyak atsiri yang dikandungnya.

Dari penelitian sebelumnya ekstrak etanol $70 \%$ kulit pisang ambon mempunyai nilai Sun Protection Factor (SPF) sebesar 11,579 (proteksi maksimal) dan nilai $\mathrm{IC}_{50}$ sebesar 121,34 ppm, termasuk antioksidan kekuatan sedang [1]. Senyawa yang memiliki peranan besar dalam niai SPF dari kulit pisang ambon yaitu senyawa flavonoid [2]. Penelitian sebelumnya belum dibuat bentuk sediaan tabir surya dari ekstrak etanol 70\% kulit buah pisang ambon. Sehingga dalam penelitian ini, ekstrak kulit buah pisang ambon diformulasikan dalam bentuk sediaan kosmetik krim tabir surya.

Antioksidan dapat menunda atau mencegah terjadinya reaksi oksidasi radikal bebas sehingga mengurangi kerusakan oksidatif yang akan mempengaruhi kesehatan kulit wajah, termasuk timbulnya jerawat. Radikal bebas adalah molekul yang mempunyai sekelompok atom dengan elektron yang tidak berpasangan [3]. Kerusakan komponen sel menyebabkan penuaan dini pada kulit yang ditandai dengan kulit kering, keriput dan kusam. Oleh karena itu, untuk mencegah terjadinya hal tersebut diperlukan suatu sediaan kosmetik yang mampu mencegah penuaan dini [4].

Spektrum sinar matahari yang mempunyai peranan pada dermatoheliosis adalah sinar ultraviolet (UV). Radiasi sinar UV menimbulkan radikal bebas pada kulit. Radikal bebas ini menghalangi difusi zat nutrisi, membuat nonaktif enzim, mengoksidasi lemak dan memecah DNA sehingga dapat membantu timbulnya keadaan prakanker. Pemberian antioksidan secara topikal digunakan untuk melindungi kulit dari kerusakan akibat oksidasi dan mencegah penuaan dini [5]. Bentuk sediaan krim dipilih karena mudah menyebar rata pada kulit, mudah meresap dan cepat kering. Sehingga tidak menimbulkan efek lengket karena tidak meninggalkan kesan berminyak pada kulit. Suatu sediaan harus memiliki stabilitas yang baik, oleh karena itu dalam penelitian ini dilakukan pengujian aktivitas antioksidan dan pengujian stabilitas fisik terhadap krim ekstrak kulit buah pisang ambon untuk melihat aktivitas antioksidan dari sediaan.

\section{METODE PENELITIAN}

Bahan: Bahan-bahan yang digunakan pada penelitian ini adalah kulit buah pisang ambon, asam stearat, setil alkohol, trietanolamin, gliserin, metil paraben, propil paraben, ammonia, kloroform, pereaksi Dragendorff, pereaksi Mayer, pereaksi Bouchardat, $\mathrm{AlCl}_{3}$ $10 \%, \mathrm{NaOH} 1 \mathrm{~N}$, asam klorida pekat, $\mathrm{FeCl}_{3}$, eter, $\mathrm{H}_{2} \mathrm{SO}_{4}$ pekat, alkohol $96 \%$, akuades, 1,1difenil-2-pikrilhidrazil (DPPH), vitamin C, dan metanol.

Alat: Alat-alat yang digunakan dalam penelitian ini adalah Spektrofotometer UV-Vis (Shimadzu UV mini 1240V), rotary evaporator (IKA RV 10 basic), timbangan digital (Acis), $\mathrm{pH}$ meter (ATC), blender (Miyako), ayakan no. 40 mesh, oven, viskometer (Brookfield MLVT115), kertas saring dan peralatan gelas. 
Metode

\section{Preparasi Sampel}

Pengumpulan buah pisang ambon dari pasar tradisional Cibubur Jakarta Timur. Kulit buah pisang ambon (Musa acuminata Colla) sebanyak $4 \mathrm{~kg}$ dicuci bersih, ditiriskan, dan dipotong kecil-kecil. Kemudian dikeringkan selama 2 hari di dalam oven dengan suhu $70^{\circ} \mathrm{C}$. Sampel diblender dan diayak dengan pengayak ukuran 40 mesh hingga menjadi serbuk kering halus sebanyak 960 gram.

\section{Penentuan Kadar Air}

Penentuan kadar air dikerjakan dengan cara cawan porselin kosong dimasukkan ke dalam oven bersuhu $105^{\circ} \mathrm{C}$ selama 1 jam. Kemudian, cawan porselen didinginkan dalam deksikator. Setelah itu cawan kosong ditimbang. Sebanyak 2 gram sampel dimasukkan ke dalam cawan porselin dan dimasukkan ke dalam oven bersuhu $105^{\circ} \mathrm{C}$ selama 3 jam. Kemudian, didinginkan dalam deksikator, dan ditimbang kembali. Perlakuan dilakukan sampai bobot cawan yang berisi sampel konstan pada saat penimbangan. Rumus perhitungan kadar air, sebagai berikut:

$$
\text { Kadar air }(\%)=\frac{a-b}{a} \times 100 \%
$$

Keterangan:

$\mathrm{a}=$ bobot sampel sebelum pemanasan $(\mathrm{g})$

$\mathrm{b}=$ bobot sampel setelah pemanasan $(\mathrm{g})$

\section{Pembuatan Ekstrak Etanol70\% Kulit Buah Pisang Ambon}

Serbuk kering kulit buah pisang ambon sebanyak $958 \mathrm{~g}$ dimaserasi dengan pelarut etanol $70 \%$ sebanyak 2,5 liter selama 24 jam, kemudian disaring dan direndam lagi dengan etanol $70 \%$ dilakukan sebanyak dua kali. Maserat dikentalkan dengan rotary evaporator dengan suhu $50^{\circ} \mathrm{C}$.

Ekstrak kental yang diperoleh kemudian dihitung persen rendemennya dengan rumus:

$$
\text { Rendemen }=\frac{\text { bobot ekstrak kental }}{\text { bobot serbuk }} \times 100 \%
$$

\section{Uji Fitokimia[6]}

a. Uji Alkaloid

Sebanyak 2 g ekstrak kental kulit buah pisang ambon dilarutkan dalam $10 \mathrm{ml}$ Kloroform ditambahkan 10 tetes $\mathrm{NH} 4 \mathrm{OH}$, disaring ke dalam tabung reaksi, filtratnya ditambahkan H2SO4 2 N kemudian dikocok selama 1 menit, didiamkan sampai terbentuk dua lapisan. Lapisan atas dimasukkan ke dalam tabung reaksi yang lain.

1. Sejumlah $1 \mathrm{~mL}$ filtrat ditambahkan 2 tetes pereaksi Bouchardat LP. Hasil positif ditunjukkan dengan adanya endapan coklat hitam.

2. Sejumlah $1 \mathrm{~mL}$ filtrat ditambahkan 2 tetes pereaksi Mayer LP. Hasil positif ditunjukkan dengan adanya endapan putih atau kuning yang larut dalam metanol P.

3. Sejumlah $1 \mathrm{~mL}$ filtrat ditambahkan 2 tetes pereaksi Dragendorff LP. Hasil positif ditunjukkan dengan adanya endapan jingga coklat.

\section{b. Uji Flavonoid}

Sebayak 0,5 g ekstrak kental kulit buah pisang ambon dilarutkan dalam $5 \mathrm{~mL}$ etanol 95\%, diambil $2 \mathrm{~mL}$ larutan ekstrak dan ditambahkan 0,1 g asam klorida pekat, dikocok perlahan. Hasil positif adanya flavonoid dengan terbentuknya warna merah jingga hingga merah ungu.

c. Uji Saponin

Sebanyak 0,5 g ekstrak kental kulit buah pisang ambon dimasukkan ke dalam tabung reaksi, ditambahkan $10 \mathrm{~mL}$ air suling panas, di dinginkan. Kemudian dikocok kuat-kuat selama 10 detik. Hasil positif ditandai dengan terbentuknya buih yang mantap selama tidak kurang dari 10 menit, setinggi $1 \mathrm{~cm}$ pada penambahan 1 tetes asam korida $2 \mathrm{~N}$ buih tidak hilang.

d. Uji Tanin

Sebanyak 0,5 g sampel dilarutkan dengan air hingga tidak berwarna. Kemudian diambil 2 $\mathrm{mL}$ dan ditetesi 1-2 tetes pereaksi $\mathrm{FeCl} 3$. Hasil uji positif ditandai dengan munculnya warna hijau, biru atau kehitaman.

e. Uji Steroid dan Triterpenoid

Sejumlah 2 g ekstrak kental masing-masing ditambahkan $20 \mathrm{~mL}$ eter dan didiamkan selama 2 jam (dalam wadah tertutup rapat) kemudian disaring dan diambil filtratnya. Sebanyak $5 \mathrm{~mL}$ filtrat tersebut diuapkan dalam cawan penguap hingga diperoleh residu. Residu ditambahkan 2 tetes asam asetat anhidrida dan $2 \mathrm{~mL}$ kloroform, kemudian ditambahkan asam sulfat pekat melalui dinding tabung. Apabila terbentuk warna merah maka menunjukkan adanya kandungan triterpenoid, sedangkan bila terbentuk warna hijau maka menunjukkan adanya senyawa steroid. 


\section{Pembuatan Krim}

Proses diawali dengan menimbang bahanbahan yang akan digunakan. Bahan-bahan yang tergolong fase minyak (Fase I) yaitu asam stearat, setil alkohol, dan propil paraben dicampur dan dipanaskan pada temperatur $70^{\circ} \mathrm{C}$. Pada bagian lain bahan-bahan yang larut air (Fase II) yaitu Trietanolamin (TEA), gliserin, dan metil paraben dicampur ke dalam akuades dan dipanaskan hingga $70^{\circ} \mathrm{C}$. Fase air kemudian ditambahkan sedikit demi sedikit ke dalam fase minyak dan dilakukan proses pengadukan pada mortir panas. Jika sudah terbentuk dasar krim maka ditambahkan ekstrak kulit buah pisang ambon, kemudian diaduk sampai homogen.

Tabel 1. Formulasi krim [7]

\begin{tabular}{|c|c|c|c|c|}
\hline \multirow[t]{3}{*}{ Fase } & \multirow[t]{2}{*}{ Bahan } & \multicolumn{3}{|c|}{ Jumlah $(\%$ b/b) } \\
\hline & & $\begin{array}{c}\text { Formula } \\
1\end{array}$ & $\begin{array}{c}\text { Formula } \\
2\end{array}$ & $\begin{array}{l}\text { Formula } \\
3\end{array}$ \\
\hline & $\begin{array}{l}\text { Ekstrak kulit } \\
\text { buah pisang } \\
\text { ambon }\end{array}$ & 5 & 10 & 15 \\
\hline \multirow[t]{2}{*}{$\mathbf{I}$} & Asam stearat & 12 & 12 & 12 \\
\hline & $\begin{array}{l}\text { Setil alkohol } \\
\text { Propil } \\
\text { paraben }\end{array}$ & $\begin{array}{c}0,2 \\
0,08\end{array}$ & $\begin{array}{c}0,2 \\
0,08\end{array}$ & $\begin{array}{c}0,2 \\
0,08\end{array}$ \\
\hline \multirow[t]{3}{*}{ II } & Trietanolamin & 2 & 2 & 2 \\
\hline & Gliserin & 10 & 10 & 10 \\
\hline & $\begin{array}{l}\text { Metil paraben } \\
\text { Akuades }\end{array}$ & $\begin{array}{c}0,1 \\
\operatorname{ad} 100\end{array}$ & $\begin{array}{c}0,1 \\
\operatorname{ad} 100\end{array}$ & $\begin{array}{c}0,1 \\
\operatorname{ad} 100\end{array}$ \\
\hline
\end{tabular}

\section{Evaluasi Sediaan Krim}

Evaluasi yang dilakukan untuk pemeriksaan mutu sediaan krim antara lain: uji organoleptik, uji $\mathrm{pH}$, uji homogenitas, uji viskositas, dan uji stabilitas fisik.

\section{a. Organoleptik}

Pengujian menggunakan panca indera. Meliputi bau, penampilan, dan warna.

\section{b. Homogenitas}

Sedikit krim dioleskan di atas kaca objek dan diamati susunan partikel yang terbentuk atau ketidakhomogenan. Krim harus menunjukkan susunan yang homogen dan tidak terlihat adanya bintik-bintik.

\section{c. Uji pH}

Dilakukan dengan menggunakan $\mathrm{pH}$ meter. pH meter dikalibrasi dengan menggunakan larutan buffer. Pengukuran dilakukan pada suhu $25^{\circ} \mathrm{C}$ dengan cara mencelupkan elektroda $\mathrm{pH}$ meter yang telah dibilas dengan aquades ke dalam sampel. Nilai $\mathrm{pH}$ ditentukan setelah angka yang terbaca pada $\mathrm{pH}$ meter stabil. Rentang toleransi $\mathrm{pH}$ pada sediaan krim berkisar antara 4,0-7,5.

\section{d. Viskositas}

Menggunakan viskometer Brookfield, dengan memasang spindle no. 4 pada alat. Kemudian, dicelupkan ke dalam sediaan sampai batas tertentu dan kecepatan $30 \mathrm{rpm}$ pada suhu $25^{\circ} \mathrm{C}$. Tiap masing-masing pengukuran dibaca skalanya (dial reading) ketika jarum merah telah stabil. Nilai viskositas dalam sentipoise (cps) diperoleh dari hasil perkalian dial reading dengan faktor koreksi untuk masing-masing spindel. Persyaratan viskositas yang baik pada sediaan semi solid adalah sebesar 4000 - 40000 cps.

\section{e. Uji daya sebar}

Pengukuran daya sebar krim dilakukan dengan meletakkan krim di tengah-tengah plastik transparan yang sudah dilapisi kertas milimeter blok. Kemudian diukur diameternya selama satu menit. Percobaan diulang dengan menambahkan beban seberat 50, 100, dan 150 gram. Perhitungan daya sebar dengan menghitung diameter permukaan sebaran. Persyaratan daya sebar yang baik pada sediaan krim yaitu $5-7 \mathrm{~cm}$.

f. Uji stabilitas fisik

Sediaan krim disimpan pada suhu kamar $\left(25^{\circ} \mathrm{C}\right)$, suhu dingin $\left(4^{\circ} \mathrm{C}\right)$, dan suhu panas $\left(40^{\circ} \mathrm{C}\right)$. Diamati setiap minggu dan diukur parameter-parameter kestabilannya yaitu bau, warna, $\mathrm{pH}$, dan viskositas selama 21 hari .

\section{Uji Aktivitas Antioksidan dengan Metode Peredaman Radikal Bebas DPPH}

Penggunaan senyawa DPPH untuk mengetahui aktivitas antioksidan dari ekstrak kental kulit buah pisang ambon dengan cara menghitung $\mathrm{IC}_{50}$, yaitu konsentrasi antioksidan yang menghambat $50 \%$ radikal bebas.

\section{a. Pembuatan larutan DPPH 100 ppm}

Ditimbang DPPH sebanyak $2 \mathrm{mg}$ lalu dilarutkan di dalam labu takar $50 \mathrm{~mL}$ dengan etanol pro analisis dalam labu takar 50,0 mL, sehingga diperoleh larutan DPPH 100 ppm.

\section{b. Pembuatan Larutan blangko}

Dipipet $1 \mathrm{~mL}$ larutan DPPH 100 ppm dimasukkan ke dalam labu ukur $5 \mathrm{~mL}$, ditambahkan etanol hingga $5 \mathrm{~mL}$. Dihomogenkan dalam wadah gelap.

\section{c. Persiapan larutan uji (ekstrak dan sediaan krim)}

Dibuat larutan ujidengan konsentrasi 50 ppm, 75 ppm, 100 ppm, 125 ppm, 150 ppm.

\section{d. Pembuatan larutan kontrol vitamin $\mathbf{C}$}

Larutan kontrol dibuat dengan cara menimbang seksama $100 \mathrm{mg}$ vitamin C, 
larutkan dalam $100 \mathrm{~mL}$ etanol proanalisis dengan konsentrasi menjadi $1000 \mathrm{ppm}$. Dibuat seri konsentrasi masing-masing $2,5 \mathrm{ppm}, 5$ ppm, 7,5 ppm, $10 \mathrm{ppm}$, dan 12,5 ppm.

\section{e. Pengujian aktivitas peredaman radikal bebas DPPH}

Pada masing-masing labu ukur ditambahkan larutan sediaan $2 \mathrm{~mL}$ dan $2 \mathrm{~mL}$ larutan $\mathrm{DPPH}$ dan $1 \mathrm{~mL}$ etanol lalu dihomogenkan. Setelah homogen diinkubasi pada suhu $37^{\circ} \mathrm{C}$ selama 30 menit. Serapan larutan diukur pada panjang gelombang maksimum menggunakan spektrofotometer UV-Vis dengan panjang gelombang $515 \mathrm{~nm}$.

\section{f. Perhitungan aktivitas peredaman radikal bebas DPPH}

Besarnya konsentrasi larutan uji untuk meredam 50\% aktivitas anti radikal bebas ditentukan dengan nilai $\mathrm{IC}_{50}$ yang dihitung berdasarkan persen peredaman radikal bebas larutan uji dengan menggunakan persamaan yang diperoleh dari kurva regresi linier. Persamaan perhitungan radikal bebas sebagai berikut:

$\%$ inhibisi $=\frac{\text { abs blanko-abs larutan } u j i}{\text { abs blanko }} \times 100 \%$

Nilai $0 \%$ berarti tidak mempunyai aktivitas antiradikal bebas, sedangkan nilai $100 \%$ berarti peredaman total dan pengujian perlu dilanjutkan dengan pengenceran bahan uji untuk melihat batas konsentrasi aktivitasnya.

\section{Uji Sun Protection Factor (SPF)}

Sebanyak 0,1 gram masing-masing krim ekstrak kulit buah pisang ambon (F1, F2, dan F3) dilarutkan dalam etanol $96 \%$ sebanyak 25 $\mathrm{mL}$ dicampur hingga homogen. Penentuan efektivitas tabir surya dilakukan dengan menentukan nilai SPF secara in vitro dengan alat spektrofotometer UV-Vis. Krim ekstrak kulit buah pisang ambon diencerkan sampai 4000 ppm. Sebelumnya spektrofotometer dikalibrasi dengan menggunakan etanol $96 \%$. Kemudian, dibuat kurva serapan uji dalam kuvet, dengan panjang gelombang 290-320 nm dengan interval $5 \mathrm{~nm}$, menggunakan etanol 96\% sebagai blanko. Kemudian, hasil absorbansi dicatat dan dihitung nilai SPF nya [8]. Nilai SPF dihitung menggunakan rumus :

$\mathrm{SPF}=\mathrm{CF} \times \sum_{320}^{290} E E(\lambda) \times \mathrm{I}(\lambda) \times \mathrm{Abs}(\lambda)$ Keterangan:

$\mathrm{EE}=$ Spektrum efek eritema

$\mathrm{I}=$ Spektrum intensitas sinar

Abs $=$ Absorbansi

$$
\mathrm{CF}=\text { Faktor koreksi }
$$

Tabel 2. Nilai EE $x$ I pada panjang gelombang 290-320 nm

\begin{tabular}{cc}
\hline $\begin{array}{c}\text { Panjang } \\
\text { Gelombang }\end{array}$ & EE x I \\
\hline 290 & 0,0150 \\
295 & 0,0817 \\
300 & 0,2874 \\
305 & 0,3278 \\
310 & 0,1864 \\
315 & 0,0839 \\
320 & 0,0180 \\
\hline Total & 1,0000
\end{tabular}

Cara perhitungan:

1. Nilai serapan yang diperoleh dikalikan dengan nilai $\mathrm{EE} \times \mathrm{I}$ untuk masingmasing panjang gelombang yang terdapat pada Tabel 2

2. Hasil perkalian serapan dan EE $x$ I dijumlahkan

Hasil penjumlahan kemudian, dikalikan dengan faktor koreksi yang nilainya 10 untuk mendapatkan nilai SPF sediaan.

\section{Analisis Data}

Analisis data dilakukan dengan menghitung persen (\%) aktivitas antioksidan yang diperoleh dari data absorbansi kemudian dilakukan perhitungan nilai $\mathrm{IC}_{50}$ dengan menggunakan persamaan regresi yang menyatakan hubungan antara konsentrasi ekstrak (x) dengan persen (\%) aktivitas antioksidan (y). Sampel yang mempunyai nilai $\mathrm{IC}_{50}$ terendah menunjukkan bahwa sampel tersebut memiliki kemampuam sebagai antioksidan yang tinggi.

\section{HASIL DAN PEMBAHASAN Simplisia}

Sampel yang digunakan pada penelitian ini adalah kulit buah pisang ambon (Musa acuminata Colla). Sebanyak $4 \mathrm{~kg}$ kulit buah pisang ambon menghasilkan $960 \mathrm{~g}$ serbuk simplisia halus. Selanjutnya diukur kadar airnya. Penetapan kadar air bertujuan untuk mengetahui kandungan air dalam simplisia tersebut, karena semakin tinggi kandungan air dalam simplisia maka semakin mudah jamur dan kapang tumbuh pada simplisia yang menyebabkan simplisia tidak tahan pada penyimpanan lama dan dapat menurunkan aktivitas senyawa aktif yang terdapat pada 
simplisia. Jumlah kadar air yang baik pada kulit buah yaitu $<10 \%$. Hasil penetapan kadar air pada penelitian ini yaitu sebesar $7 \%$, menunjukkan kadar air pada simplisia tersebut memenuhi persyaratan kadar air pada simplisia.

\section{Hasil Pembuatan Ekstrak}

Serbuk simplisia yang diekstraksi sebanyak 958 gram menggunakan metode maserasi. Metode ini dipilih karena paling mudah dan sederhana, tidak memerlukan peralatan yang khusus serta suhu yang yang digunakan rendah sehingga dapat mencegah penguraian senyawa yang tidak tahan panas. Dipilih etanol sebagai pelarut karena etanol bersifat polar sehingga dapat menarik senyawa-senyawa polar seperti flavonoid, saponin, tanin dan lain-lain. Diperoleh ekstrak cair sebanyak 5 liter. Setelah dipekatkan dengan ekstrak rotary vacuum evaporator pada suhu $50^{\circ} \mathrm{C}$, didapatkan ekstrak kental sebanyak 351,25 gram berwarna hitam berbau khas. Hasil rendemen yang didapat yaitu sebanyak $36,6 \%$.

\section{Hasil Pengujian Fitokimia Ekstrak Etanol 70\% Kulit Buah Pisang Ambon}

Pengujian fitokimia pada penelitian ini bertujuan untuk mengetahui senyawa yang terkandung di dalam ekstrak. Hasil uji fitokimia pada ekstrak etanol $70 \%$ kulit buah pisang ambon menunjukkan hasil positif pada senyawa flavonoid, saponin, dan tanin.

Tabel 3. Hasil Penapisan Fitokimia Ekstrak Etanol 70\% Kulit Pisang Ambon

\begin{tabular}{lc}
\hline Golongan senyawa & Pengamatan \\
\hline Alkaloid: & - \\
Mayer & - \\
Bouchardat & - \\
Dragendorff & + \\
Flavonoid & + \\
Saponin & + \\
Tanin & - \\
Steroid dan triterpenoid & \\
\hline
\end{tabular}

Keterangan :

(+) : Positif, mengandung zat aktif

$(-)$ : Negatif, tidak mengandung zat aktif

\section{Pembuatan Krim}

Proses diawali dengan menimbang bahanbahan yang akan digunakan. Bahan-bahan yang larut air (Fase II) seperti TEA, gliserin, metil paraben dicampur ke dalam akuades dipanaskan hingga $70^{\circ} \mathrm{C}$. Pada bagian lain bahan-bahan yang tergolong fase minyak (Fase I) seperti asam stearat, setil alkohol, dan propil paraben dicampur dan dipanaskan pada temperatur yang sama $70^{\circ} \mathrm{C}$.

Fase air kemudian ditambahkan sedikit demi sedikit ke dalam fase minyak dan dilakukan proses pengadukan pada mortir panas. Jika sudah terbentuk dasar krim maka ditambahkan ekstrak kulit buah pisang ambon kemudian diaduk sampai homogen.

\section{Hasil Evaluasi Fisik Sediaan Krim \\ a. Pemeriksaan organoleptik \\ Pemeriksaan organoleptik krim meliputi pemeriksaan warna, aroma, dan tekstur.}

\section{Tabel 4. Hasil Pemeriksaan Organoleptik}

\section{Krim}

\begin{tabular}{llll}
\hline Krim & Warna & Aroma & Tekstur \\
\hline F1 (5\%) & Agak kecoklatan & + & Lembut \\
$\begin{array}{l}\text { F2 } \\
(\mathbf{1 0 \%})\end{array}$ & Coklat muda & ++ & Lembut \\
$\begin{array}{l}\text { F3 } \\
(\mathbf{1 5 \%})\end{array}$ & Coklat tua & +++ & Lembut \\
$\begin{array}{l}\text { Basis } \\
\text { krim }\end{array}$ & Putih susu & - & \\
\hline
\end{tabular}

Keterangan:

$+\quad$ : aroma kulit pisang ambon lemah

$+\quad$ : aroma kulit pisang ambon sedang

$++\quad$ : aroma kulit pisang ambon kuat

- $\quad$ : tidak beraroma

Warna coklat dari sediaan diakibatkan oleh penambahan ekstrak kulit pisang ambon. Hal ini dibuktikan sebelum penambahan ekstrak etanol kulit pisang ambon warna basis krim berwarna putih. Aroma atau bau yang dihasillkan adalah khas kulit pisang ambon. Aroma yang dihasilkan krim ekstrak kulit pisang ambon tergantung dari konsentrasi ekstrak yang ditambahkan dalam sediaan krim. Semakin tinggi konsentrasi ekstrak maka aroma yang yang dihasilkan semakin meningkat, dari ketiga formula yang paling kuat aroma kulit pisang ambon yaitu, formula 3 karena konsetrasi yang ditambahkan ke dalam sediaan krim paling besar dibandingkan formula 1 dan 2.

b. Homogenitas 
Berdasarkan pemeriksaan homogenitas, sediaan F1, F2, dan F3 yaitu homogen. Krim dinyatakan homogen apabila mempunyai tekstur yang tampak rata dan tidak menggumpal.

\section{c. Hasil pH krim}

Ekstrak kulit buah pisang ambon memiliki $\mathrm{pH}$ asam yaitu $\mathrm{pH} 4$, sehingga semakin banyak konsentrasi ekstrak kulit buah pisang ambon yang ditambahkan semakin asam $\mathrm{pH}$ krim yang dihasilkan. Nilai $\mathrm{pH}$ basis krim adalah 6,8 . Nilai $\mathrm{pH}$ sediaan krim tabir surya berkisar di 4,5-7. Jika pH krim terlalu basa akan menyebabkan kulit bersisik sedangkan jika terlalu asam menimbulkan iritasi kulit Hasil pengujian $\mathrm{pH}$ dapat dilihat pada Gambar 1.

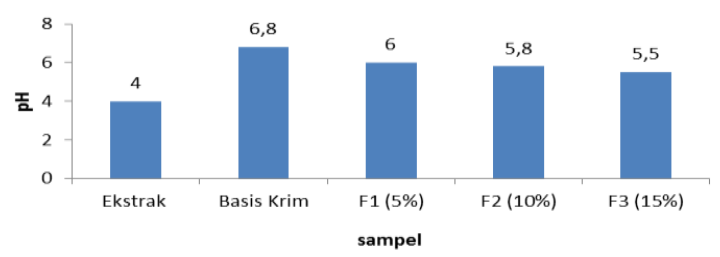

Gambar 1. Diagram Hasil Pengujian pH

\section{d. Viskositas}

Berdasarkan hasil pengujian, viskositas krim tidak mengalami penurunan dari minggu ke 1 dan minggu ke 3 pada suhu 25C. Semakin besar konsentrasi ekstrak dalam krim semakin kental, dikarenakan perhitungan basis krim untuk air digantikan dengan ekstrak kulit buah pisang ambon. Untuk penurunan viskositas terjadi di minggu ke-3 pada suhu $40^{\circ} \mathrm{C}$. Sedangkan kenaikan viskositas terjadi pada minggu ke 3 pada suhu $4^{\circ} \mathrm{C}$.

Persyaratan viskositas yang baik untuk sediaan semi solid adalah sebesar 4000 - 40000 cps Berdasarkan hasil pengujian pada penelitian ini viskositas pada ketiga formula memenuhi syarat persyaratan viskositas.

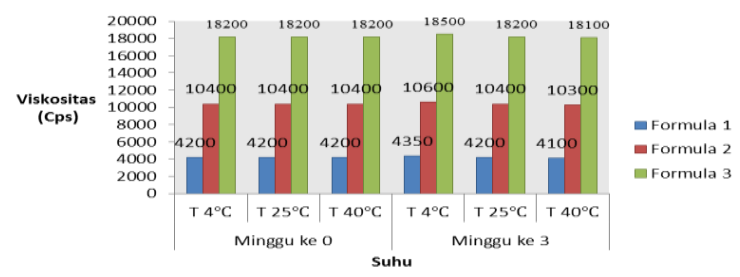

Gambar 2. Diagram Viskositas Sediaan Krim Ekstrak Kulit Buah Pisang Ambon

e. Hasil Uji Daya Sebar

Uji daya sebar krim dilakukan untuk mengetahui kemampuan menyebar krim saat diaplikasikan ke kulit. Permukaan penyebaran yang dihasilkan dengan bertambahnya beban menggambarkan karakteristik daya sebar [8]. Luas permukaan yang dihasilkan berbanding lurus dengan kenaikan beban yang ditambahkan. Hasil uji daya sebar dapat dilihat pada Tabel 5.

Tabel 5. Hasil Uji Daya Sebar Krim Tabir Surya Ekstrak Kulit PisangAmbon

\begin{tabular}{llll}
\hline $\begin{array}{lll}\text { Beban } \\
\text { (gram) }\end{array}$ & \multicolumn{4}{l}{ Uji Daya Sebar $(\mathbf{c m})$} \\
\cline { 2 - 3 } & $\begin{array}{l}\text { F1 } \\
\mathbf{( 5 \% )}\end{array}$ & F2 (10\%) & F3 (15\%) \\
$\mathbf{5 0}$ & 5,5 & 4,3 & 3,9 \\
$\mathbf{1 0 0}$ & 6,2 & 5,1 & 5 \\
$\mathbf{1 5 0}$ & 7,9 & 5,6 & 5,5 \\
\hline
\end{tabular}

F1 lebih luas penyebarannya daripada F2 dan F3, ini disebabkan F2 dan F3 lebih kental dibandingkan dengan F1. Semakin tinggi viskositas krim semakin kecil daya sebarnya. Persyaratan uji daya sebar untuk sediaan krim yang baik adalah 5-7 cm. Krim formula 1 tidak memenuhi persyaratan uji daya sebar karena nilainya lebih dari $7 \mathrm{~cm}$. Hal ini disebabkan karena krim formula 1 lebih banyak kandungan airnya.

Hasil Uji Antioksidan Ekstrak Kental dan Krim Ekstrak Etanol 70\% Kulit Buah Pisang Ambon

Besarnya aktivitas antioksidan ditandai dengan nilai $\mathrm{IC}_{50}$. Nilai $\mathrm{IC}_{50}$ merupakan konsentrasi sampel yang dapat meredam DPPH sebanyak $50 \%$. Semakin kecil nilai $\mathrm{IC}_{50}$ berarti semakin tinggi aktivitas antioksidan. Hasil pengujian aktivitas antioksidan dapat dilihat pada Tabel 6 .

Tabel 6. Hasil Uji Antioksidan

\begin{tabular}{lcc}
\hline \multicolumn{1}{c}{ Sampel } & $\begin{array}{c}\text { Nilai IC } \\
\text { (ppm) }\end{array}$ & $\begin{array}{c}\text { Kategori } \\
{[\mathbf{1 0}]}\end{array}$ \\
\hline $\begin{array}{l}\text { Vitamin C } \\
\text { Ekstrak kulit } \\
\text { pisang ambon }\end{array}$ & 3,13 & $\begin{array}{c}\text { Sangat Aktif } \\
\text { Aktif }\end{array}$ \\
$\begin{array}{l}\text { Formula 3(15\%) } \\
\text { Formula 2 (10\%) }\end{array}$ & $\begin{array}{c}107,04 \\
\text { Formula 1 (5\%) }\end{array}$ & Aktif \\
\hline
\end{tabular}

Aktivitas antioksidan setelah dibuat sediaan menjadi lebih lemah dibanding ekstrak karena kemungkinan terjadi reaksi antara basis krim dan ekstrak. 


\section{Hasil Pengujian Sun Protection Factor}

Pengukuran nilai SPF menggunakan spektrofotometer UV-Vis Shimadzu UV mini$1240 \mathrm{~V}$ dengan rentang panjang gelombang 290$320 \mathrm{~nm}$. Sampel sebanyak $100 \mathrm{mg}$ dilarutkan dalam etanol $96 \%$ sebanyak $25 \mathrm{ml}$ dicampur hingga homogen. Kemudian diukur serapannya. Sebelumnya spektrofotometer UV-Vis dikalibrasi dengan menggunakan etanol $96 \%$. Hasil uji nilai SPF dapat dilihat pada Tabel 7.

Tabel 7. Hasil Pengujian Nilai SPF

\begin{tabular}{lll}
\hline Sampel & SPF & Proteksi \\
\hline $\begin{array}{l}\text { Ekstrak kulit } \\
\text { pisang ambon }\end{array}$ & 33,30 & Ultra \\
Formula 3 (15\%) & 13,72 & Maksimal \\
Formula 2 (10\%) & 11,65 & Maksimal \\
Formula 1 (5\%) & 8,61 & Maksimal \\
\hline
\end{tabular}

Hubungan Nilai SPF dengan Nilai $\mathrm{IC}_{50}$ Antioksidan

Kulit buah pisang ambon memiliki salah satu kandungan terpenting yaitu flavonoid yang berperan sebagai antioksidan dan berguna sebagai bahan aktif tabir surya. Berdasarkan pada hasil penelitian didapat hubungan aktivitas antioksidan dan nilai SPF menunjukkan adanya hubungan. Semakin besar aktivitas antioksidannya maka semakin besar nilai SPF krim. Hasil nilai SPF dan nilai $\mathrm{IC}_{50}$ dapat dilihat pada Tabel 8 .

Tabel 9. Hasil nilai $\mathrm{IC}_{50}$ dan nilai SPF

\begin{tabular}{lll}
\hline Sampel & IC $_{\mathbf{5 0}}(\mathbf{p p m})$ & SPF \\
\hline F1 (5\%) & 117 & 8,61 \\
F2 (10\%) & 107,11 & 11,65 \\
F3 (15\%) & 92,04 & 13,72 \\
$\begin{array}{l}\text { Ekstrak kulit } \\
\text { pisang ambon }\end{array}$ & 88,12 & 33,30 \\
\hline
\end{tabular}

\section{SIMPULAN}

Berdasarkan hasil penelitian yang dilakukan maka dapat disimpulkan sebagai berikut :

a. Ekstrak etanol $70 \%$ kulit buah pisang ambon dapat dibuat krim tabir surya dengan mutu fisik yang baik.

b. Aktivitas antioksidan dari ekstrak etanol $70 \%$ kulit buah pisang ambon, F1, F2, dan F3 masing-masing sebesar 88,12 ppm (aktif), $117 \mathrm{ppm}$ (sedang), 107,11 ppm (sedang), dan 92,04 ppm (aktif).

c. Nilai SPF pada sediaan krim F1, F2, dan F3 masing-masing sebesar 8,61; 11,65; dan 13,72 . Ketiga formula tersebut termasuk kategori proteksi maksimal. d. Krim tabir surya dari ekstrak etanol $70 \%$ kulit buah pisang ambon stabil pada suhu $25^{\circ} \mathrm{C}$, karena konsistensi krim tidak berubah.

\section{DAFTAR PUSTAKA}

[1] Kurniati, I., 2018. Aktivitas Antioksidan dan Faktor Pelindung Surya dari Partisi Pelarut Ekstrak Kulit Buah Pisang Ambon Putih (Musa acuminata AAA). Sekolah Tinggi Teknologi Industri dan Farmasi: 25; 27

[2] Abdi Redha, 2010, Flavonoid Struktur, Sifat Antioksidan dan Peranannya dalam Sistem Biologis, Http://repository polnep. ac.id.

[3] Sudarto, P., H. Sutisna, dan T. Achmad. (2002). Buku ajar patologi I (umum). Jakarta : Sagung Seto: 21-23.

[4] Elsner, P. and I.M. Horward. 2000. Cosmeceuticals Drugs vs Cosmetics. Marcel Dekker Inc. New York. Hlm: 16, $145,163$.

[5] Herling and Zastrow, L., 2001, Dangerous Free Radical in Skin Generated by UV-A Irradiation, SOFW Journal 127, 24-32.

[6] Harbone, J.B. 1987. Metode Fitokimia, Penuntun Cara Modern Menganalisa Tumbuhan. Terjemahan Kosasih Padmawinata. Edisi II. Bandung. ITB Press: 147.

[7] Iswindari, D., (2014). Formulasi dan Uji Aktivitas Antioksidan Krim Rice Bran Oil. Jakarta. Fakultas Kedokteran dan Ilmu Kesehatan UIN Syarif Hidayatullah.

[8] Voight, R. 1994. Buku Pelajaran Teknologi Farmasi. Diterjemahkan oleh Soewandi, S.N. Yogyakarta. Gadjah Mada University Press.

[9] Yulianti, B. Aldesa, A. Putri, A. 2015. Penentuan Nilai SPF (Sun Protecting Factor) Ekstrak Etanol 70\% Temu Mangga (Curcuma mangga) Dan Krim Ekstrak Etanol 70\% Temu Mangga (Curcuma mangga) Secara In Vitro Menggunakan Metode Spektrofotometri. Majalah Kesehatan. 2(1): 43.

[10 Jun, M.H.Y., J. Yu, X. Fong, C.S. Wan, C.T. Yang, and Ho. 2003. Comparison of antioxidant activities of isoflavones from 
81 Herson Cahaya Himawan et al. (Aktivitas Antioksidan Dan Spf Sediaan...)

kudzu root (Pueraria labata Ohwl). J.

Food Sci. Institute of Technologist. 68:

2117-21. 